\author{
Magdalena KOZUB-KARKUT \\ Uniwersytet Jagielloński \\ magdalenakozub@gmail.com
}

\title{
POLSKI SPÓR O IN VITRO
}

\section{PRÓBA CHARAKTERYSTYKI DYSKURSU PUBLICZNEGO ${ }^{1}$}

\section{ABSTRACT The Polish dispute over in vitro. The character of public debate}

The aim of the article is to present the polish discourse on in vitro fertilization (IVF) and law regulation related to this issue. This article investigates the discursive strategies presented in the political discourse as well as in the part of public discourse, where the positions of proponents and opponents of the IVF are articulated. The publication presents the arguments of the Catholic clergy as well as activists and journalists associated with the Church (mainly presented in the press and on the Internet). In addition, the article shows the views of those who are strongly engaged in the promotion of the in vitro fertilization in Poland (their arguments are mostly presented in the press, media as well as on the Internet websites that were established especially for this reason). The article analyses the question of the identity of those who are IVF children and who recently are also taking part in the public debate related to this issue. The method, that has been chosen for the investigation, is the sociological discourse analysis, which enables to understand the social world (and political as well) from within while focusing on sense and reference of communication acts. Consequently, it can be applied to studying N. Luhmann's system theory that assumes the investigation of the social system from within its own functioning.

Keywords: in vitro, public discourse, sociological discourse analysis

Słowa kluczowe: in vitro, dyskurs publiczny, socjologiczna analiza dyskursu

\footnotetext{
1 Artykuł powstał w ramach projektu badawczego pt. „Miejsce religii w sferze publicznej. Tożsamości religijne w wieloreligijnych regionach Europy Środkowo-Wschodniej na przykładzie wybranych regionów Polski, Ukrainy i Słowacji”. Projekt realizowany z funduszy Narodowego Centrum Nauki, konkurs OPUS VI, umowa nr UMO-2013/09/B/HS6/03076.
} 


\section{WPROWADZENIE}

Głównym celem artykułu jest przedstawienie polskiego dyskursu na temat zapłodnienia in vitro (ang. in vitro fertilization - IVF) i ewentualnych regulacji prawnych dotyczących tej kwestii. Publikacja odwołuje się w szczególności do tych wątków debaty publicznej, które podjęte zostały przy okazji prac nad podpisaną 22 lipca 2015 roku przez Prezydenta RP Ustawą o leczeniu niepłodności. Debata ta przebiegała w Polsce w sposób niezwykle burzliwy nie tylko dlatego, że włączyli się w nią przedstawiciele Kościoła katolickiego, ale także z powodu trwających niemal w tym samym czasie dwóch kampanii wyborczych: prezydenckiej i parlamentarnej. Czas wyborów jest zawsze szczególną okazją do wywoływania sporów światopoglądowych, prowadzących w konsekwencji do polaryzacji sceny politycznej.

Zapłodnienie in vitro definiowane jest na potrzeby publikacji zgodnie z polską debatą dotyczącą tego zagadnienia, a więc jako taka „technika wspomaganego rozrodu”, która zakłada połączenie komórek rozrodczych poza organizmem matki, w warunkach laboratoryjnych - „w szkle”2. In vitro, nie ogranicza się de facto wyłącznie do jednego tylko modelu zapłodnienia, ale jako że głównym celem artykułu jest analiza polskiej debaty publicznej, przyjęlam taką definicję, która w niej funkcjonuje i w której in vitro oznacza tyle, co zapłodnienie poza organizmem. Terminy „zapłodnienie in vitro”, ,procedura in vitro", ,in vitro”, „zapłodnienie pozaustrojowe” i „zapłodnienie na szalce Petriego" stosuję w niniejszym artykule zamiennie.

Dotychczasowy brak przepisów regulujących to zagadnienie w Polsce ${ }^{3}$ był właściwie sam w sobie zaczynem konfliktów i jednocześnie argumentem promotorów tej metody, którym posługiwali się w dyskusjach ${ }^{4}$. Jakiekolwiek próby zmierzające do ustawo-

Zapłodnienie in vitro jako jedna z technik wspomaganego rozrodu (ang. assisted reproductive technolo$g y$ - ART) określane jest w literaturze przedmiotu jako różne sposoby mające na celu uzyskanie ciąży z pominięciem jednego lub kilku etapów właściwych dla naturalnego poczęcia. Poza zapłodnieniem in vitro, które polega na doprowadzeniu do połączenia komórki jajowej i plemnika w warunkach laboratoryjnych, do technik wspomaganego rozrodu zalicza się między innymi inseminację. Należy też nadmienić, że sam termin „zapłodnienie in vitro” jest określeniem, które w debacie publicznej często używane jest zbiorczo dla określenia różnych specyficznych typów zapłodnienia pozaustrojowego, z których najczęściej stosuje się metodę ICSI (ang. intracytoplasmic sperm injection), polegającą na wstrzykiwaniu wyselekcjonowanego plemnika bezpośrednio do cytoplazmy komórki jajowej, a nie tylko na połączeniu tych dwóch komórek w warunkach laboratoryjnych na tzw. szalce Petriego. Dla większości uczestników debaty in vitro oznacza po prostu zapłodnienie poza organizmem matki. Por. M. Radkowska-Walkowicz, Doświadczenie in vitro. Nieptodność i nowe technologie reprodukcyjne w perspektywie antropologicznej, Warszawa 2013, s. 263-266.

3 Do Sejmu VI kadencji wpłynęło w sumie sześć projektów ustaw prezentujących różne stanowiska dotyczące zapłodnienia in vitro, od najbardziej restrykcyjnego, który zakazywał tej procedury pod groźbą kary pozbawienia wolności do lat trzech, do najbardziej liberalnego projektu dopuszczającego procedurę zapłodnienia in vitro dla konkubinatów, kobiet samotnych i par homoseksualnych. Więcej na ten temat w: tamże, s. 48-49.

4 Polska jest ostatnim państwem Unii Europejskiej, które do 2015 roku nie posiadało żadnych przepisów regulujących kwestię zapłodnienia in vitro. We wrześniu 2013 roku Komisja Europejska pozwała 
wej regulacji procedur związanych z in vitro natychmiast stawały się przyczyną ostrych sporów natury ideologicznej. Podobnie jak ma to miejsce w przypadku dyskusji toczonych wokół kwestii aborcji, płci kulturowej (ang. gender), kwestii refundacji środków antykoncepcyjnych czy obecności symboli religijnych w przestrzeni publicznej5.

Przedmiotem analizy niniejszego artykułu będzie dyskurs polityki, ale także część dyskursu publicznego, w którym artykułowane są stanowiska zarówno przeciwników, jak i zwolenników in vitro. Analizie poddane zostaną stanowiska prezentowane przez polskich polityków i wyrażane głównie podczas debat parlamentarnych czy wystąpień w mediach. Ponadto przedmiotem analizy będą argumenty formułowane przez hierarchów Kościoła katolickiego w Polsce oraz dziennikarzy prezentujących podobne stanowisko. Poza tymi stanowiskami do analizy włączony zostanie też głos zwolenników tej metody zapłodnienia - polityków, dziennikarzy, publicystów i aktywistów społecznych.

Tak określony polski dyskurs dotyczący kwestii zapłodnienia pozaustrojowego wpisany zostanie w specyfikę polskiej debaty publicznej, która od 1989 roku często odwołuje się do procesów transformacji ustrojowej, demokratyzacji i europeizacji. Taki kontekst sprawia, że dyskusja na temat in vitro dotyczy nie tylko spraw związanych z wyborami moralnymi czy koniecznością przyjęcia odpowiednich rozwiązań natury prawnej, ale także porusza problemy związane z rolą i pozycją Kościoła katolickiego w polskim społeczeństwie czy po prostu miejscem religii w polskiej przestrzeni publicznej. ${ }^{6}$. Ponadto dyskurs ten wpisuje się w procesy związane z funkcjonowaniem pluralizmu religijnego w Polsce i jego transformacją, wynikającą z zasygnalizowanych wcześniej procesów modernizacji. Jest to zagadnienie o tyle ważne, że sama dotycząca go debata publiczna staje się już nie tylko okazją do wymiany poglądów i przedstawienia własnych argumentów, ale także formą dialogu, w którym dokonuje się proces określania własnej tożsamości. Ten ostatni w polskich warunkach wpisany jest także w proces przechodzenia z rzeczywistości PRL do demokracji, w którym na nowo określana jest tożsamość jednostek - także ta religijna.

\section{Źródła}

Przystępując do analizy polskiego dyskursu publicznego, wskazać należy na źródła, które na potrzeby niniejszej publikacji wybrane zostały jako jego elementy składowe, jak również na samą jego definicję. Za Markiem Czyżewskim definiuję dyskurs publiczny

Polskę za niewdrożenie trzech dyrektyw, które opisują między innymi normy pobierania, przetwarzania, przechowywania komórek rozrodczych i zarodków oraz definiują zasady funkcjonowania ośrodków medycznie wspomaganej prokreacji. Trybunał Sprawiedliwości UE wydał wyrok orzekający, że Polska naruszyła przepisy unijne, nie przyjmując regulacji w sprawie in vitro. Był to jednak wyrok w tzw. trybie ostrzegawczym i Trybunał nie wymierzył Polsce kary pieniężnej.

5 Por. M. Kozub-Karkut, D. Głuszek-Szafraniec, Miejsce krzyża w przestrzeni publicznej - analiza wybranych debat, „Studia Religiologica” 2016, z. 1, [online] http://www.ejournals.eu/Studia-Religiologica/Tom-49-2016/Numer-49-1-2016/art/7281, 20 VI 2016, https://doi.org/10.4467/2 0844077SR.16.004.4904.

6 Por. M. Radkowska-Walkowicz, Frozen children and despairing embryos in the new post-communist state. Debate on IVF in the context of Poland's transition, „European Journal of Women's Studies” 2014, Vol. 21, nr 4, s. 1-16, [online] https://doi.org/10.1177/1350506814542881. 
jako wszystkie przekazy dostępne publicznie, a więc: dyskursy instytucjonalne, dyskursy związane z określonymi grupami społecznymi, dyskurs środków masowego przekazu, dyskurs polityki oraz dyskurs polityczny, czyli dyskurs elit symbolicznych. Dyskurs polityki określony został jako część dyskursu publicznego, jakkolwiek współcześnie, w dobie globalizacji i rosnącej roli mediów masowych, granica pomiędzy nimi staje się coraz bardziej płynna. Niejednokrotnie wystąpienia parlamentarne, zaliczane do dyskursu polityki, przyjmują swoją ostateczną postać właśnie dlatego, że dzięki medialnej transmisji ich autorzy „mówią” nie tylko do osób obecnych na sali obrad, ale także do publiczności obecnej via media.

Grupa analizowanych w publikacji wypowiedzi obejmuje debaty parlamentarne ${ }^{7}$ oraz stanowiska polityków prezentowane podczas udzielanych wywiadów czy w programach telewizyjnych. Na potrzeby artykułu zostaną one jednak zawężone do tych, które powołują się na argumenty Kościoła katolickiego oraz tych przywołujących kwestie związane z manifestowaniem tożsamości religijnej w przestrzeni publicznej.

Ponadto analizie poddane zostaną też wypowiedzi prezentujące stanowisko Kościoła katolickiego. Podstawowym ich źródłem będą stanowiska i listy hierarchów kościelnych (dokumenty Komisji Episkopatu Polski), jak również ich wypowiedzi dla mediów czy też same artykuły publikowane w czasopismach katolickich (np. „Gość Niedzielny" "). Ich uzupełnieniem będą także stanowiska dziennikarzy i publicystów podzielających te poglądy, przedstawiane zarówno w prasie (np. „Rzeczpospolita”), jak i na portalach internetowych (np. Fronda.pl).

Ponadto przedstawiona w publikacji analiza uwzględnia stanowiska zwolenników tej metody zapłodnienia, między innymi: polityków, dziennikarzy, publicystów czy osób po prostu zaangażowanych w promowanie in vitro, aktywnych zarówno w prasie („Gazeta Wyborcza”, „Newsweek”), jak i na stronach i forach internetowych (między

W niniejszym artykule analizie poddane zostaną debaty parlamentarne z 2015 roku, kiedy Sejm VII kadencji rozpatrywał cztery zgłoszone projekty ustaw o leczeniu niepłodności: projekt rządowy, przyjęty ostatecznie w formie ustawy (i); poselski projekt ustawy o zmianie ustawy o pobieraniu, przechowywaniu i przeszczepianiu komórek, tkanek i narządów, autorstwa SLD (ii); poselski projekt ustawy o ochronie genomu ludzkiego i embrionu ludzkiego oraz zmianie niektórych innych ustaw, autorstwa PiS, zakazujący de facto procedury in vitro (iii) oraz projekt ustawy o świadomym rodzicielstwie, autorstwa SLD (iv). Projekty trzeci i czwarty Sejm odrzucił w pierwszym czytaniu.

8 Od początku stycznia do końca lipca 2015 roku ukazało się w tym tygodniku ponad 10 tekstów poświęconych bezpośrednio kwestii zapłodnienia in vitro lub poruszających ten problem pośrednio, np. poprzez porównanie in vitro z naprotechnologią. Są to zarówno artykuły, jak i wywiady z osobami zaangażowanymi w promowanie metod leczenia niepłodności alternatywnych wobec in vitro.

9 Warty odnotowania jest fakt, że w drukowanych numerach tygodnika „Newsweek” w 2015 roku temat in vitro pojawia się bardzo rzadko. Od stycznia do lipca 2015 roku redakcja nie poświęciła tej tematyce żadnego dłuższego tekstu, a zagadnienie to pojawiało się przy okazji takich tematów, jak: spory światopoglądowe kampanii prezydenckiej, niepłodność czy eksperymenty na embrionach. Ponadto temat in vitro poruszano w wywiadach między innymi z kard. Kazimierzem Nyczem i prof. Andrzejem Jaczewskim. Zupełnie inne wyniki pokazuje internetowy portal newsweek.pl. Po wpisaniu frazy „in vitro” do wyszukiwarki i zaznaczeniu przedziału czasowego od 1 stycznia do 31 lipca 2015 roku, wyświetla się 44 pozycji, z czego 33 zakwalifikować można jako teksty dotyczące in vitro, koncentrujące się szczególnie na przebiegu prac nad ustawą o leczeniu niepłodności. Pozostałe są między innymi satyrami lub komentarzami. 
innymi Nasz Bocian - forum Stowarzyszenia na Rzecz Leczenia Niepłodności i Wspierania Adopcji) czy po prostu wypowiadających się publicznie.

Analiza wszystkich przywołanych wypowiedzi wskazuje na występujące w nich argumenty odwołujące się do wiary - głównie katolickiej, dlatego że to Kościół katolicki zajmuje najbardziej radykalne stanowisko w tej sprawie ${ }^{10}$. Ponadto uwzględnione zostały te wątki debaty, które jednoznacznie osadzają dyskurs w kontekście transformacji ustrojowej i demokratyzacji. Te ostatnie, według Ireny Borowik, wyostrzyły pytania o tożsamość i wzajemne relacje pomiędzy tożsamością a religią. Po procesie transformacji ustrojowej religia w państwach Europy Środkowo-Wschodniej mogła „powrócić” na swoje miejsce i być na nowo określana jako wolność przynależna jednostce, z której ta ostatnia może swobodnie korzystać ${ }^{11}$. Jak pokazały debaty publiczne już w latach 90 . XX wieku, proces wspomnianego „powrotu” okazał się jednak bardzo trudny, a system religii, choć odgrywa sporą rolę w legitymizowaniu polityki, na nowo określa swoje relacje z pozostałymi systemami, takimi jak np. kultura, edukacja czy właśnie polityka. Zasadne wydaje się zatem pytanie o polski współczesny model relacji polityka-religia, który wciąż dostosowuje się do wymogów nowoczesnego państwa demokratycznego i który wciąż kontestowany jest przez głównych aktorów sceny politycznej.

\section{Podstawy teoretyczne i metoda}

Metodą wybraną dla analizy wyżej wymienionych treści jest socjologiczna (jakościowa) analiza dyskursu, która poprzez badanie sensów i form wypowiedzi tekstowych ${ }^{12}$ pozwala zrozumieć świat społeczny, w tym także polityczny, „od wewnątrz” i przez to współgra

10 Kościół ewangelicko-augsburski na świecie nie wypracował jednolitego stanowiska w kwestii zapłodnienia in vitro, a w Polsce odpowiednie stanowisko zaprezentowane zostało przez Synod Kościoła w 2009 roku, w którym oświadczono, że polscy luteranie opowiadają się za akceptacją stosowania metody in vitro jako drogi leczenia niepłodności, przy jednoczesnym stanowczym podkreśleniu sprzeciwu wobec tworzenia i przechowywania zamrożonych embrionów nadliczbowych bez wyraźnego celu późniejszej implantacji do organizmu matki. Z kolei jedynym dokumentem greckokatolickim odnoszącym się do in vitro jest katechizm Chrystus Nasza Pascha (2011), zgodnie z którym dopuszczalność zapłodnień in vitro przeciwstawia się integralnej koncepcji natury i osoby ludzkiej stworzonej przez Boga, skłania do uprzedmiotowienia człowieka, ma destrukcyjny wpływ na pojmowanie miłości mężczyzny i kobiety itd., a więc jest niemal tożsame ze stanowiskiem Kościoła katolickiego. W islamie natomiast o zarodku, jako osobie ludzkiej, można mówić dopiero od setnego dnia ciąży. Jak wskazała jednak M. Radkowska-Walkowicz, w kwestii in vitro głosy innych Kościołów niż katolicki nie są właściwie w ogóle słyszalne. Zob. F.B. Hamida, Moralność muzutmańska wobec medycyny i biotechnologii, [w:] Medycyna a prawa cztowieka. Normy i zasady prawa międzynarodowego, etyki oraz moralności katolickiej, protestanckiej, żydowskiej muzutmańskiej i buddyjskiej, przeł. I. Kaczyńska, Warszawa 1996, s. 45-48; Synod o dopuszczalności in vitro, 19 IV 2009, [online] http://old.luteranie.pl/pl/?D=2676, 30 VII 2015; Grekokatolicy i prawostawni o in vitro, [online] http://www.grekokatolicy.pl/aktualnosci/grekokatolicy-i-prawoslawni-wobec-in-vitro.html, 30 VII 2015.

11 I. Borowik, Religia jako element tożsamości w warunkach transformacji w Europie Środkowo-Wschodniej, [w:] Państwo - spoteczeństwo - religia we wspótczesnej Europie, red. M. Mróz, T. Dębowski, Toruń 2009, s. 17-35.

12 L. Chiouliaraki, Discourse Analysis, [w:] The SAGE Handbook of Cultural Analysis, eds. T. Bennett, J. Frow, Los Angeles 2008, s. 674-698. 
z przyjętą podstawą teoretyczną - systemową teorią Niklasa Luhmanna, zakładającą badanie systemu społecznego z pozycji wytworzonej przez jego wnętrze ${ }^{13}$. Badacz posługujący się socjologiczną analizą dyskursu rozumie „tekst” jako każdy obiekt lub czynność, które są obdarzone społecznym znaczeniem. Są to: słowa umieszczone w strukturach ponadzdaniowych, wyodrębnione ciągi wypowiedzi słownych, obrazy i społeczne działania. Zgodnie z poglądem Piotra Pawliszaka i Doroty Rancew-Sikory to, co przesądza o tym, że przeprowadzona analiza jest analizą dyskursu, to wykazanie, że analizowane wypowiedzi zakorzenione są w konkretnym kontekście, w którym zostały skonstruowane i przekazane odbiorcom ${ }^{14}$. Socjologiczna analiza dyskursu pozwala na badania o charakterze interdyscyplinarnym, uwzględniające wiele różnych punktów widzenia. Każda wypowiedź, dyskusja, debata telewizja, analizowane przy pomocy tej metody, rozpatrywane są jako jednostki semiotyczne zanurzone w bezpośrednim tekście towarzyszącym oraz w kontekście intertekstualnym i społeczno-politycznym ${ }^{15}$, a więc, używając terminologii Teuna van Dijka, analiza dyskursu jest analiza tekstu $w$ kontekście $^{16}$. Dyskurs jest bowiem określany jako obszar działań i interakcji społecznych, a zdarzenia komunikacyjne, które go tworzą, składają się z kolei z różnych aktów mowy, osadzonych w różnych sytuacjach w obrębie jednego społeczeństwa i danej kultury ${ }^{17}$.

Powyższe założenia są spójne z teorią Luhmanna, który zdefiniował system społeczny właśnie jako system komunikacji, ze szczególną rolą przypisaną „znaczeniu” a to ostatnie istotne miejsce zajmuje także w analizie dyskursu. Według Luhmanna współczesne społeczeństwa nie są społeczeństwami zintegrowanymi, lecz złożonymi z „funkcjonalnych podsystemów”, autonomicznych i o ograniczonej zdolności komunikowania się ze sobą. Modernizacja i globalizacja wymusiły na systemie społecznym „dyferencjację funkcjonalną”, której konsekwencją jest wydzielenie się funkcjonalnych ośrodków (subsystemów): polityki, prawa, ekonomii, edukacji, religii ${ }^{18}$.

Poprzez system Luhmann rozumie sensowny związek społecznych oddziaływań, które odnoszą się do siebie nawzajem. System istnieje tylko dzięki temu, że odróżnia

13 Socjologiczną analizę dyskursu powiązał także z teorią Niklasa Luhmanna Błażej Skrzypulec, analizując regulacje prawne dotyczące handlu tzw. „dopalaczami”. Por. B. Skrzypulec, Dyskurs na temat legalnych substancji psychoaktywnych w perspektywie teorii systemowej Niklasa Luhmanna, „Studia Socjologiczne" 2004, Vol. 1, nr 204, s. 149-176.

14 P. Pawliszak, D. Rancew-Sikora, Wprowadzenie do socjologicznej analizy dyskursu, „Studia Socjologiczne" 2012, Vol. 1, nr 204, s. 6.

15 R. Wodak, Wstęp: Badania nad dyskursem - ważne pojęcia i terminy, [w:] Jakościowa analiza dyskursu w naukach spotecznych, red. nauk. R. Wodak, M. Krzyżanowski, przeł. D. Przepiórkowska, Warszawa 2011, s. 13, Biblioteka Dyskursu Publicznego.

16 T.A. van Dijk, Badania nad dyskursem, [w:] Dyskurs jako struktura i proces, red. tenże, przeł. G. Grochowski, Warszawa 2001, s. 10.

17 Tamże.

18 Etap powstania takiego społeczeństwa poprzedzało społeczeństwo ustrukturowane hierarchicznie, kierowane przez tzw. „klasę wyższą” - arystokrację. O przewodzenie społeczeństwu konkurowały ze sobą: polityka i religia. Zob. A. Dziuban, System religijny $w$ dobie globalizacji. Inkluzja i fundamentalizm z perspektywy teorii systemowej Niklasa Luhmanna, „Poznańskie Studia Teologiczne” 2008, Vol. 22, s. 320 . 
się od środowiska, a odróżnienie to dokonywane jest przez sam system. Pojęcie systemu odsyła zatem samo do siebie, nie można dokonać obserwacji systemu „poza systemem”. W konsekwencji system nie może istnieć samodzielnie, lecz tylko w relacji do otoczenia $^{19}$. Zgodnie z tym konstruktywistycznym założeniem system społeczny znajduje się nieustannie w stadium „stawania się”. Autor łączy jednak swoją koncepcję systemu społecznego z aktem komunikacji, który też traktuje procesualnie, jako niekończący się ciąg wydarzeń. System luhmannowski nie jest systemem działań ani nawet nie jest systemem złożonym z ludzi, lecz z komunikacji. To proces komunikacji decyduje u Luhmanna nie tylko o samym kształtowaniu się systemu, ale także o jego podziale na inne podsystemy. Ludzie nie są elementami systemu, na który składają się raczej ich społeczne role czy akty komunikacji ${ }^{20}$.

System społeczny odróżnia się od otoczenia poziomem złożoności, który w otoczeniu zawsze jest wyższy aniżeli w samym systemie. Złożoność definiowana jest jako tak duża ilość możliwych relacji pomiędzy jego elementami, że niewykonalna jest jednoczesna realizacja wszystkich możliwości i w konsekwencji niektóre muszą pozostać niezrealizowane. Nie wszystko w systemie może się wydarzyć, ale właśnie dzięki temu posiada on swoją tożsamość, która odróżnia go od otocznia. Otoczenie systemu, jako że nie posiada już tej cechy i wszystko może się w nim wydarzyć, staje się automatycznie mniej przewidywalne. Terminem wprowadzonym do analizy systemu przez Luhmanna jest „autopoietyczność" systemu, a więc proces jego samoreprodukcji. System sam wytwarza swoje elementy składowe, sam też wyznacza swoje granice. Współgra to także z założeniami Luhmanna dotyczącymi współczesnego, zglobalizowanego społeczeństwa, które jest nie tylko coraz bardziej kompleksowe i złożone, ale także nieustannie poszerza swoje komunikacyjne granice. Autor nazywa takie społeczeństwo światowe policentrycznym i polikontekstualnym ${ }^{21}$. System jest autoreferencyjny, a więc nie wykonuje żadnych operacji poza sobą samym, a każda operacja w jego obrębie jest jedynie reprodukcją. Jest to jego „operacyjna zamkniętość”. System społeczny według Luhmanna jest jednak otwarty poznawczo, to znaczy, że odnosi się on do swojego otoczenia, co biorąc pod uwagę powyższe założenia, jest niezbędne do jego istnienia. Odnoszenie do otoczenia nie odbywa się jednak poprzez bezpośredni kontakt, ale za pomocą wewnętrznie wytworzonych reprezentacji. System społeczny Luhmanna istnieje tylko wówczas, gdy odróżnia się od otoczenia, a żeby się odróżniać, musi nieustannie redukować swoją złożoność, tak by pozostawać mniej złożonym od środowiska. Wszelkie aktywności w obrębie systemu zmierzają właśnie do redukcji złożoności czy kompleksowości.

Przedmiotem zainteresowania niniejszego artykułu będą wyróżnione przez Luhmanna subsystemy polityki i religii, które reagując na wzrastający poziom swojej

19 N. Luhmann, Systemy spoteczne. Zarys ogólnej teorii, przeł. M. Kaczmarczyk, Kraków 2007, s. 23, Wspótczesne Teorie Socjologiczne, 1; G. Skąpska, Wstęp, [w:] N. Luhmann, Teoria polityczna państwa bezpieczeństwa socjalnego, przeł. G. Skąpska, Warszawa 1994, s. 7-18.

20 G. Skąpska, Niklas Lubmann i teoria systemów spotecznych. Wstęp do wydania polskiego, [w:] N. Luhmann, Systemy spoteczne..., s. XI. Zob. także: B. Skrzypulec, Dyskurs na temat..., s. 155.

21 Zob. A. Dziuban, System religijny..., s. 319-336; J. Szacki, Historia myśli socjologicznej, Warszawa 2006, s. 937-941. 
złożoności, starają się ją redukować. Religia, zgodnie z założeniem Luhmanna, w nowoczesnym, zglobalizowanym (światowym) społeczeństwie stała się subsystemem, zmieniając swoją rolę w środowisku, w którym nie ma już miejsca na „święty baldachim”. Warte zaznaczenia jest także założenie o tym, że każdy z subsystemów jest odrębny i charakteryzuje się własnymi autopoietycznymi zachowaniami, właściwymi tylko dla niego. Każdy subsystem wytwarza charakterystyczne dla siebie kody znaczeń, które są oparte na binarnych opozycjach, np. dla systemu polityki: rząd-opozycja, dla systemu prawa: legalne-nielegalne. Ponadto każdy subsystem funkcjonuje w oparciu o trzy typy zależności systemowych: stosunek systemu do całości (funkcja systemu religijnego realizowana jest przez Kościól jako nośnik komunikacji), relacje z innymi subsystemami (w przypadku subsystemu religii jest to diakonia) i odniesienia do samego siebie ${ }^{22}$.

Zgodnie z przyjętym założeniem zapowiedź minister zdrowia Ewy Kopacz z 2007 roku dotycząca regulacji prawnej kwestii zapłodnienia in vitro stała się przyczyną procesów komplikacji w obrębie systemów: polityki i religii. Perspektywa regulacji prawnej procedury zapłodnienia pozaustrojowego, a więc tej, która od lat $80 . \mathrm{XX}$ wieku funkcjonuje w Polsce legalnie, ale jednocześnie bez podstawy prawnej, spowodowała "komplikacje” w obu systemach i stała się przyczyną debat ujawniających ich nowe podziały i „złożoności”. Celem publikacji będzie zatem próba odpowiedzi na pytanie, w jaki sposób systemy polityki i religii reagują na wspomniane komplikacje i w jaki sposób dążą do redukcji swojej złożoności. Redukcja złożoności, zgodnie z przedstawionymi wcześniej założeniami, odbywa się w warunkach polskiej transformacji ustrojowej i społecznej, w nieustannym nawiązaniu do pozostałości po okresie PRL. Jej tłem jest także ostry spór światopoglądowy, w którym uczestniczący politycy, dziennikarze, publicyści, a także zwykli obywatele wyrażają swoje poglądy, konstruując jednocześnie swoją tożsamość (także religijną) i określając zakres, przynależnej im w ramach społeczeństwa ponowoczesnego, wolności. Tożsamość jednostek i grup uczestniczących w dyskursie konstruowana jest w warunkach „przejścia” od pluralizmu tradycyjnego do nowoczesnego i zakłada możliwość korzystania z różnych tradycji i w oparciu o różne wzorce publicznego manifestowania więzi z religią.

\section{POLSKA DEBATA O IN VITRO - STRUKTURA ARGUMENTÓW}

Kwestia zapłodnienia in vitro pojawiła się w polskiej debacie publicznej już pod koniec lat 80 . XX wieku, a więc w czasie wykonania pierwszego tego typu zabiegu w naszym kraju. Dyskurs ten przybrał nieco na sile w latach 90. XX wieku, kiedy Polska wkroczyła na drogę transformacji ustrojowej i wiele sporów o charakterze światopoglądowym rozpoczęto niejako „na nowo"23. Niemniej jednak dopiero w ostatnich latach, a konkretniej

\footnotetext{
22 A. Dziuban, System religijny..., passim.

23 Por. Cudze problemy. O ważności tego, co nieważne, red. M. Czyżewski, K. Dunin, A. Piotrowski, Warszawa 1991; Rytualny chaos. Studium dyskursu publicznego, red. M. Czyżewski, S. Kowalski, A. Piotrowski, Kraków 1997.
} 
od 2007 roku, debata staje się coraz bardziej zażarta i nazywana bywa niekiedy „drugim sporem o aborcję"24. Bez względu na to, jak bardzo radykalizował się sam dyskurs, pojawiały się w nim (i nadal pojawiają) przede wszystkim dwie grupy argumentów.

Po pierwsze debata odwołuje się do statusu zarodka, przywołując pytanie, czy powstający z połączenia z dwóch komórek (jajowej i plemnikowej) embrion jest już człowiekiem i czy w związku z tym uprawnione jest jego niszczenie, mrożenie, poddawanie eksperymentom itp. Zarodek, cytując Magdalenę Radkowską-Walkowicz, stał się w polskim dyskursie publicznym ważnym graczem politycznym i, co istotne, „zamrożony zarodek" zaistniał w debacie publicznej o wiele później aniżeli w laboratoryjnej rzeczywistości ${ }^{25}$. Kobiety, które poddawały się zabiegom zapłodnienia in vitro jeszcze na początku lat 90. XX wieku, nie miały aż tak dużej świadomości na temat samej procedury, nie wiedziały, że w jej rezultacie powstaje przynajmniej kilka zarodków, i w związku z tym nie zadawały sobie pytania o ich przyszłość. Status „zarodka” i jego miejsce w debacie publicznej są o tyle istotne, że to od tego, czy potraktujemy zarodek jako osobę ludzką, człowieka czy jedynie zespół komórek, zależy nasz stosunek do in vitro w ogóle. Przeciwnicy tej metody zapłodnienia przywołują w tym sporze argumenty nie tylko Kościoła katolickiego, które wskazują, że życie ludzkie zaczyna się od poczęcia i od tej chwili powinno być chronione, ale także odwołują się do warstwy etycznej i wartości uniwersalnych, uzasadniając swój sprzeciw tym, że człowiek nie może decydować o życiu czy przetrwaniu drugiego człowieka, dokonując selekcji embrionów. Paradoksalnie w tej warstwie sporu Kościół stara się przywoływać argumenty, których dostarcza mu nauka ${ }^{26}$ lub filozofia ${ }^{27}$, sugerując, że to nie sama religia

24 Na początku lat 90. XX wieku polską scenę polityczną zdominował spór o aborcję, dopuszczalną w czasach PRL-u z tzw. „przyczyn społecznych”. W 1989 roku wniesiono do Sejmu poselski projekt ustawy zwanej później „antyaborcyjną, który rozpoczął polską debatę na temat dopuszczalności prawa do tzw. „aborcji na życzenie”. Spór, choć pozornie zażegnany ustawą z 1993 roku i jej nowelizacją z 1996 roku, toczy się w polskiej debacie publicznej aż do dzisiaj.

25 W pierwszych latach stosowania in vitro najczęściej transferowano do organizmu kobiety wszystkie uzyskane zarodki, co niejednokrotnie związane było z dokonaniem tzw. „selektywnej aborcji”. Pierwsze metody mrożenia wprowadzono w latach 80 . XX wieku, a dopiero kilka lat temu wprowadzono nitryfikację, która pozwala mrozić zarodki bez uszczerbku dla nich. Dlatego też, jak pisze Magdalena Radkowska-Walkowicz, kobiety, które poddały się in vitro w latach 90. XX wieku w Polsce, niejednokrotnie nie wiedziały nawet, ile zarodków powstało, ile zostało przetransferowanych i co stało się z pozostałymi. Por. M. Radkowska-Walkowicz, Doświadczenie..., s. 168.

26 Wiedza naukowa, a wręcz sama procedura in vitro, w której właśnie moment połączenia komórek: męskiej i żeńskiej, a więc zapłodnienia, uznawany jest za początek nowego życia, dostarcza argumentu przeciwnikom in vitro. Wskazują oni, że życie człowieka zaczyna się właśnie w chwili połączenia komórek na szkle, i od tego momentu powinno być chronione przez prawo. Mamy do czynienia z paradoksem, w którym owoce nauki świadczą przeciwko niej. Por. M. Radkowska-Walkowicz, Doświadczenie..., s. 142. Ponadto sami przeciwnicy in vitro przywołują w swoich wypowiedziach poglądy między innymi genetyków. W artykule opublikowanym w „Gościu Niedzielnym” Bogumił Łoziński pisze, że żaden poważny genetyk nie zaprzeczy temu, iż ludzkie istnienie zaczyna się w momencie poczęcia. Zob. B. Łoziński, Argument przeciwko in vitro, „Gość Niedzielny” 2015, 22 II.

27 Do założeń filozoficznych odwołują się w swoich wypowiedziach zarówno posłowie, jak i publicyści reprezentujący stanowisko Kościoła katolickiego. Zazwyczaj przywołują założenie Immanuela Kanta o tym, że cztowieka nie można rozpatrywać jako środka do osiagnięcia celu, gdyż jest on celem samym 
(a tym bardziej nie tylko Kościół instytucjonalny) jest przeciwna in vitro. Druga strona sporu zupełnie inaczej definiuje pojęcie „zarodka”. Jest on w jej argumentacji traktowany raczej jako „zbiór komórek”, a więc w ten sam sposób, w jaki określiła go przyjęta w Polsce ustawa. W wywiadzie dla „Newsweeka” prof. Andrzej Jaczewski sugeruje, że życie człowieka zaczyna się nie w momencie połączenia komórek, lecz w chwili ich zagnieżdżenia się w organizmie kobiety. W momencie połączenia na szkle komórki są jedynie „potencjalnym człowiekiem”, który bez organizmu matki nigdy nie powstanie ${ }^{28}$. W ten sposób zwolennicy metody in vitro włączają do debaty kolejny wątek, a mianowicie zagadnienie „potencjalności”, rozpoczynając na nowo dyskusję o początku człowieczeństwa.

Po drugie zatem polski dyskurs dotyczący analizowanego problemu dotyczy także samego momentu połączenia dwóch komórek, a więc zapłodnienia, które zdaniem przeciwników in vitro zostaje oderwane od aktu małżeńskiego. Ta druga grupa argumentów bardzo głośno wyrażana jest przez hierarchów i księży Kościoła katolickiego. O ile bowiem postęp nauki daje nadzieję na to, że w przyszłości będzie można uniknąć procedury mrożenia tzw. „zarodków nadliczbowych” i pozwolić na zapłodnienie i transfer do organizmu kobiety wyłącznie jednego, o tyle sensem zapłodnienia in vitro jest właśnie fakt łączenia komórek w laboratorium i dla Kościoła katolickiego „przeszkoda" ta nigdy nie będzie mogła zostać wyeliminowana. Dobrze oddaje to wypowiedź o. Jacka Salija: tam, gdzie naprawdę nie ma zabijania embrionów, jest zdecydowanie mniej nieporzadku moralnego. Mimo wszystko jednak nie można uznać tej drogi starania się o ciążę i o urodzenie dziecka za moralnie dopuszczalną ${ }^{29}$.

W dokumencie Donum vitae (Instrukcja o szacunku dla rodzacego się życia ludzkiego i o godności jego przekazywania. Odpowiedzi na niektóre aktualne zagadnienia) jasno wskazano, że dziecko ma prawo do tego, by zostać poczętym, by być noszonym w tonie, narodzonym i wychowywanym $w$ matżenstwie. W dokumencie można przeczytać także, że FIVET ${ }^{30}$ dokonuje się poza ciatem matżonków za pośrednictwem dziatania osób trzecich [...]. FIVET powierza więc życie i tożsamość embrionów w ręce wtadzy lekarzy i biologów ${ }^{31}$. Takie stanowisko jednoznacznie opowiada się przeciwko zapłodnieniu in vitro i jednocześnie radykalizuje dyskurs dotyczący tej kwestii, zamykając właściwie drogę do dialogu z przeciwnikami. Ci ostatni twierdzą, że procedura zapłodnienia in vitro nie

w sobie. W przypadku in vitro, zdaniem jego przeciwników, mamy do czynienia z posługiwaniem się człowiekiem dla realizacji konkretnego celu. Stąd też ich opinia, że in vitro gubi szacunek dla cztowieka na każdym etapie procedury. Zob. „Gość Niedzielny” 2015, 22 III.

W. Staszewski, Czy Bóg lubi seks? Wywiad z prof. Andrzejem Jaczewskim, „Newsweek” 2015, 27 VII.

O. J. Salij, O zaptodnieniu in vitro porozmawiajmy spokojnie, 12 V 2008, [online] http://www.stronaoinvitro.pl/salij-in-vitro, 17 VIII 2015.

Termin FIVET to skrót włoskiego określenia fecondazione in vitro e transferimento dell'embrione, które oznacza zapłodnienie in vitro i transfer embrionu. Najczęściej skrót ten występuje w thumaczeniu dokumentów Kościoła katolickiego.

31 Instrukcja o szacunku dla rodzaccego się życia ludzkiego i o godności jego przekazywania. Odpowiedzi na niektóre aktualne zagadnienia, 22 II 1987, [online] http://www.vatican.va/roman_curia/congregations/cfaith/documents/rc_con_cfaith_doc_19870222_respect-for-human-life_pl.html, 11 VIII 2015. 
jest tylko technologiczna proteza ptodności ${ }^{32}$, lecz po prostu imituje naturę, dając nadzieję tysiącom par na kawatek wtasnego szczęścia 33 .

Te dwie grupy argumentów zdominowały polską debatę o in vitro i chociaż są co jakiś czas uzupełniane o dodatkowe wątki, to stanowią wciąż główne linie podziału. W ciągu ostatnich kilku lat w polskim dyskursie zaobserwować można jednak pewną zmianę, którą obecnie trudno jeszcze jednoznacznie określić jako mniej lub bardziej istotną. Debata na temat in vitro w Polsce wzbogaciła się o kolejny wątek - poruszyła problemy, z którymi borykać się mogą w przyszłości dzieci poczęte tą metodą. I również w przypadku tego zagadnienia mamy do czynienia z nowymi argumentami, które nie dotyczą już samych ewentualnych chorób czy wad genetycznych bądź też kwestii związanych z ciążą czy porodem (ciąże mnogie, wcześniactwo, hipotrofia itp.), ale uwypuklają problemy związane z tożsamością osób poczętych na szalce Petriego. Problem tożsamości tych osób pojawił się w polskim dyskursie w 2012 roku, kiedy zorganizowana została konferencja z okazji 25-lecia in vitro w Polsce. Wtedy, jak uznała Radkowska-Walkowicz, dzieci z in vitro zaistniały w polskim dyskursie jako pełnoprawne podmioty ${ }^{34}$. „Dzieci z in vitro” w swoich wypowiedziach wskazują też na 2010 rok, kiedy podczas kampanii wyborczej jedno $\mathrm{z}$ nich spotkało się z kandydatem na prezydenta Bronisławem Komorowskim.

Socjologiczna analiza dyskursu pozwala w zebranych i wskazanych powyżej danych dyskursywnych wyróżnić kilka istotnych kategorii analitycznych, którymi posługują się uczestnicy debaty o in vitro. Po pierwsze „nominalizacja” oznaczająca sposób, w jaki osoby poczęte metodą in vitro są „społecznie konstruowane” poprzez nadawanie im odpowiednich określeń35. Po drugie „orzekanie”, czyli wskazanie na odpowiednie cechy przywołanych wyżej konkretnych aktorów społecznych ${ }^{36}$. Po trzecie „argumentacja” wskazująca, za pomocą jakich argumentów i schematów argumentacyjnych uczestnicy debaty starają się uzasadnić swoje stanowiska (czyli uzasadnić lub obalić twierdzenie zawierające konkretne przykłady nominalizacji i orzekania). Po czwarte „perspektywizacja”, a więc wskazanie na punkty widzenia, z jakich wyrażane są przykłady nominalizacji i orzekania. Piąta z kategorii analitycznych wskazuje natomiast, czy nominalizacja, orzekanie i argumentacja są intensyfikowane i wypowiadane jawnie, czy też są tonowane ${ }^{37}$. W niniejszym artykule skoncentruję się na trzech pierwszych kategoriach,

32 Określenia tego użyła posłanka Małgorzata Sadurska w wypowiedzi dla Programu Pierwszego Polskiego Radia, [online] http://www.polskieradio.pl/7/473/Artykul/1416858,In-vitro-znow-w-Sejmie-To-jest-spor-swiatopogladowy, 16 VIII 2015.

33 Cytat z wypowiedzi premier RP Ewy Kopacz po uchwaleniu przez Sejm ustawy o leczeniu niepłodności, [online] https://www.premier.gov.pl/wydarzenia/aktualnosci/sejm-uchwalil-ustawe-o-in-vitro-premier-ewa-kopacz-dotrzymalam-slowa.html, 11 VIII 2015.

34 M. Radkowska-Walkowicz, Doświadczenie..., s. 183-187.

35 Określenia te nadają im nie tylko zwolennicy i przeciwnicy in vitro, ale także oni sami, a więc już dorosłe osoby, które publicznie przyznają, że zostały poczęte metodą zapłodnienia pozaustrojowego.

36 Należy jednak dodać, że te dwie kategorie niejednokrotnie występują jednocześnie i trudno wyraźnie je od siebie oddzielić. Nazwanie osoby poczętej metodą in vitro bardzo często zawiera już w sobie pewien konkretny zestaw przypisanych jej społecznie cech.

37 Za: M. Reisigl, Analiza retoryki politycznej, [w:] Jakościowa analiza dyskursu..., s. 156. 
próbując wskazać, jak określane są osoby z in vitro, jakie cechy są im przypisywane i jakie argumenty przywołują uczestnicy debaty.

\section{SZCZĘŚCIE Z PROBÓWKI - PRZYKŁADY NOMINALIZACJI I ORZEKANIA}

Osoby poczęte metodą in vitro funkcjonują w polskiej debacie publicznej w dwóch rolach. W pierwszej - jako przedmiot debaty, do którego odwołują się przeciwnicy i zwolennicy zapłodnienia in vitro. Druga rola takich dzieci zakłada ich funkcjonowanie jako odrębnej grupy uczestniczącej w debacie obok swoich rodziców, a czasami zupełnie niezależnie. W tej roli występują już jako świadome swoich poglądów podmioty toczącej się dyskusji, której niejednokrotnie same nadają konkretny kierunek.

Najczęściej stosowane w polskiej debacie określanie osób poczętych metodą in vitro to niesławne „dziecko z probówki” ${ }^{38}$, którym posługują się zarówno przeciwnicy (którzy wprowadzili ten termin do debaty), jak i zwolennicy omawianej metody. Co więcej, określenie to pojawia się już właściwie jako termin „neutralny”, między innymi w serwisach informacyjnych. Tytuł wiadomości dostępnej na stronie internetowej dziennik.pl z 2 lipca 2012 roku brzmi: Urodzito sięuż 5 milionów dzieci z probówki, dowodząc tym samym, że określenie to funkcjonuje wręcz jako zamiennik terminu in vitro. Podobnie w wiadomości opublikowanej na portalu gazeta.pl z 16 listopada 2012 roku zatytułowanej: Magdapierwsze polskie dziecko z probówki - pokazata twarz. Termin „dziecko z probówki”, kiedyś kojarzący się jednoznacznie negatywnie i podkreślający odmienny od naturalnego sposób poczęcia, stygmatyzował tych, którzy urodzili się dzięki tej metodzie. Obecnie funkcjonuje w polskiej debacie zupełnie neutralnie. W ten sposób użyto go także w artykule opublikowanym w katolickim portalu gosc.pl w artykule zatytułowanym Obtęd Edwardsa ${ }^{39}$, $\mathrm{w}$ którym już w pierwszych zdaniach pojawia się pytanie o to, jak powstawato pierwsze dziecko z probówki $i^{40}$. Przywołać można także artykuły z portalu fronda.pl, zatytułowane: Dlaczego nienawidzę dzieci z probówki ?+1 , Chore dzieci z probówki ${ }^{42}$, Mój ojciec nazywa się

38 W połowie listopada 1987 roku, po narodzinach pierwszego dziecka z in vitro, „Express Wieczorny" na pierwszej stronie poinformował: 12 listopada br. szcześliwe narodziny „dziecka z probówki” w Instytucie Potożnictwa i Chorób Kobiecych AM w Biatymstoku byty efektem pozaustrojowego zaptodnienia, które nastapito w kraju, wtaśnie w Biatymstoku. Określenie „dziecko z probówki” zapisano w cudzysłowie, który dzisiaj jest już pomijany. W kolejnych latach termin ten stosowali głównie przeciwnicy tej metody.

39 Artykuł opisuje prace Roberta Edwardsa, który za doprowadzenie do zapłodnienia pozaustrojowego otrzymał w 2010 roku Nagrodę Nobla.

40 J. Butkiewicz-Brożek, Obtęd Edwardsa, „Gość Niedzielny” 2015, 2 VII, [online] http://gosc.pl/ doc/2569238. Obled-Edwardsa, 14 VIII 2015.

41 M. Stępień, Dlaczego nienawidzę dzieci z probówki, 2VII 2012, [online] http://www.fronda.pl/blogi/ gloria-tibi-domine/dlaczego-nienawidze-dzieci-z-probowki,28590.html, 16 VIII 2015.

42 Choredziecizprobówki, 24 III 2009, [online] http://www.fronda.pl/a/chore-dzieci-z-probowki,1288. html, 16 VIII 2015. 
Dawca, czyli co trapi dzieci z próbówki?ł3. Zawarte w nich odniesienie do osób poczętych metodą in vitro określane jest dodatkowo, a termin „dziecko z probówki” funkcjonuje jako ich synonim.

Terminem „dziecko z probówki” posługują się także w stosunku do siebie osoby poczęte metodą in vitro. Posługując się nim, określają swoją tożsamość głównie na portalach i forach internetowych, gdzie często pozostają anonimowi, ale także w prasie czy telewizji, ujawniając już swoje dane, a niejednokrotnie także wizerunek. Odwołują się także do innych niesławnych określeń, między innymi ks. Tadeusza Pieronka, który w 2009 roku porównał in vitro do literackiego wyobrażenia Frankensteina ${ }^{44}$, oraz do wypowiedzi ks. prof. Franciszka Longchamps de Bériera, sugerującego, że dzieci poczęte podczas zaptodnienia pozaustrojowego maja dodatkowa bruzde dotykowa na twarzy i sa lekarze, którzy po pierwszym spojrzeniu na twarz dziecka wiedza już, że zostato poczęte metoda in vitro ${ }^{45}$. Do tych porównań odwołała się w jednym z wywiadów Agnieszka Ziółkowska (pierwsza Polka poczęta in vitro, która urodziła się we Włoszech), stwierdzając: my, dzieci z in vitro, nie jesteśmy dziećmi jakiegoś gorszego Boga, tylko tego samego, w którego wierzy ksiądz profesor, choćstuchając jego stygmatyzująych wypowiedzi, można zaczać $w$ to wątpić, że w niego wierzy ${ }^{46}$. Do określenia użytego przez ks. Pieronka Ziółkowska jasno odwołała się także w swoim liście opublikowanym w „Gazecie Wyborczej”, w którym wypowiedziała się niejako w imieniu wszystkich poczętych in vitro: $M y$, dzieci Frankensteina. Żyjemy, pracujemy, kochamy oraz gtosujemy ${ }^{47}$.

Poza tymi określeniami odnaleźć można w literaturze przedmiotu i artykułach prasowych także szereg innych, które zaliczyć można zarówno do procedury nominalizacji, czyli nadawania znaczeń, jak i orzekania, czyli wskazywania na konkretne cechy osób $\mathrm{z}$ in vitro. Niemniej jednak w samej debacie publicznej używa się najczęściej przywołanych już określeń: „dzieci z probówki” lub po prostu „dzieci z in vitro”. Zyskujące

43 „Mój ojciec nazywa się Dawca”, czyli co trapi dzieci z próbówki?, 14 VI 2010, [online] http://www.fronda.pl/a/moj-ojciec-nazywa-sie-dawca-czyli-co-trapi-dzieci-z-probowki,6939.html, 17 VIII 2015.

44 T. Pieronek, Pierwowzorem in vitro jest Frankeinstein, w rozmowie z W. Harpulą 15 I 2009, [online] http://wiadomosci.onet.pl/pierwowzorem-in-vitro-jest-frankenstein/x4d6q, 12 VIII 2015.

45 W wywiadzie dla czasopisma „Uważam Rze” pojawiło się określenie „bruzda dotykowa”, choć później ks. Longchamps de Bérier tłumaczył, że miał na myśli „bruzdę dodatkową” na twarzy osób poczętych metodą in vitro. Ta „literówka” nie zmienia jednak wiele w samym dyskursie na temat in vitro, mówienie o bruździe „dotykowej” lub „dodatkowej” dla osób urodzonych dzięki tej metodzie jest przejawem stygmatyzacji. Zob. F. Longchamps de Bérier, In vitro niczego nie zatatwia, rozmowa z T. Krzyżakiem, „Uważam Rze” 2013, 28 II; Ksiądz ttumaczy się ze stów o bruzdach na twarzach dzieci z in vitro, [online] http://www.tvn24.pl/wiadomosci-z-kraju,3/ksiadz-tlumaczy-sie-ze-slow-o-bruzdach-na-twarzach-dzieci-z-in-vitro,308217.html, 13 VIII 2015.

46 M. Zawała, Agnieszka Ziótkowska to najstarsze w Polsce dziecko poczęte metoda in vitro, [online] http:// www.dziennikzachodni.pl/artykul/793914,agnieszka-ziolkowska-to-najstarsze-w-polsce-dziecko-poczete-metoda-in-vitro,id,t.html, 13 VIII 2015.

47 A. Ziółkowska, My, dzieci Frankensteina. Żyjemy, pracujemy, kochamy oraz GEOSUJEMY. Nie zapomnimy Wam tej dyskusji [list o in vitro], „Gazeta Wyborcza” 2015, 9 VII, [online] http://wyborcza. $\mathrm{pl} / 1,95892,18331376$,my-dzieci-frankensteina-zyjemy-pracujemy-kochamy-oraz-glosujemy.html, 13 VIII 2015. 
złą sławę „dzieci Frankensteina”, charakteryzowane jako koszmarne, chore i potamane ${ }^{48}$, choć mają swoje miejsce w dyskursie, to nie są zbyt często przywoływane przez samych uczestników debaty.

\section{„MY TO WSZYSTKO SŁYSZYMY...” - ARGUMENTACJA DYSKURSU}

W swojej publikacji Magdalena Radkowska-Walkowicz, opisując rolę, jaką w polskiej debacie publicznej odgrywają dzieci z in vitro, przyznała, że sama też przyczynia się do ich esencjalizowania. Wskazuje je jako osobną kategorię dzieci, pacjentów czy jednostek medycznych. W niniejszym artykule ta grupa osób także jest esencjalizowana i określona mianem odrębnych uczestników samej debaty o in vitro. Nie jest ich wiele, bo polski dyskurs o in vitro ma zaledwie kilka swoich bohaterek: Agnieszkę, Magdę, Konstancję i Karolinę ${ }^{49}$. Pierwsza z nich nazwana została nawet „siłaczką” za to, że niestrudzenie tłumaczy ludziom, że nie jest dzieckiem Frankensteina. Choć bohaterek jest niewiele, ich głos, przy okazji prac nad ustawą o leczeniu niepłodności, był jednak obecny w polskiej debacie, szczególnie przy okazji niesławnych dyskusji w Senacie. Ich obecność trafnie oddaje wypowiedź Agnieszki Ziółkowskiej z 2012 roku: Zapominamy, że polskie dzieci $z$ in vitro są coraz większe, niektóre mogtyby już mieć wtasne dzieci. I śledza tę debatę petna bzdur i wyzwisk [...]. My to wszystko styszymy, czytamy, ten caty ściek nie leci w próżnię ${ }^{50}$.

Polski dyskurs o in vitro nie może już dłużej ignorować tego, że osoby, o których mówi się, że mają skłonności do pewnej grupy chorób, narodziły się kosztem swojego rodzeństwa czy wreszcie że są owocem gwałtu na naturze; mogą nie tylko poczuć się dotknięte, ale co ważniejsze, mogą także zabrać głos w dyskusji. Nie są już tylko „ocaleńcami”, lecz dorosłymi ludźmi, obywatelami, a niejednokrotnie także katolikami, wierzącymi, że są dziećmi tego samego Boga, który nie chce ich karać tylko za to, że nie poczęły się w sypialni rodziców. Dla polskiej dyskusji o in vitro, wpisującej się w szerszą debatę na temat relacji religia-polityka, ich głos ma niemałe znaczenie. Określając siebie jako osobną kategorię, definiują swoją tożsamość w nieustannym odwołaniu do metody, dzięki której przyszli na świat. A poprzez odwołania do wiary katolickiej stają się także dowodem na zmiany dokonujące się w samym procesie budowania tożsamości. Ta ostatnia konstruowana jest już selektywnie i bazuje na wartościach z różnych źródeł, nie tylko religijnych.

Istotne w samej debacie jest także i to, że to właśnie przeciwnicy in vitro podkreślają w swojej argumentacji fakt, iż życie człowieka i samo człowieczeństwo zaczyna się od poczęcia i od poczęcia zasługuje na ochronę. Dowodzi tego choćby wypowiedź

48 Zelnik: rodza się z tego in vitro dzieci koszmarnie chore, potamane. Ekspert: gruba przesada, wypowiedź Jerzego Zielnika w programie „Tak jest”, w telewizji TVN24, 28 V 2015, [online] http://www.tvn24. $\mathrm{pl}$ /wiadomosci-z-kraju,3/jerzy-zelnik-i-maciej-malenczuk-w-tak-jest-spor-o-in-vitro, 546318.html, 14 X 2015.

49 M. Radkowska-Walkowicz, Doświadczenie..., s. 186-187.

50 A. Ziółkowska, Niepokalanie poczęta. Agnieszka, najstarsze w Polsce dziecko z in vitro, „Gazeta Wyborcza” 2012, 30 VII, [online] http://wyborcza.pl/energiakobiet/1,118219,12200284,Niepokalanie_ poczeta_Agnieszka_najstarsze_w_Polsce.html, 13 VIII 2015. 
posłanki Małgorzaty Sadurskiej: Każdemu cztowiekowi, niezależnie od tego, czy jest w fazie embrionalnej, czy w tonie matki, czy juz się urodzit, przystuguje caty katalog praw, a te najważniejsze to prawna ochrona życia i poszanowanie godności $i^{51}$. Podobnie poseł Czesław Hoc przypomina, że dzieci z in vitro są żywym darem Bożej dobroci, a więc wymagaja, jak każda osoba ludzka, poszanowania, mitości i szacunku².

Także przedstawiciele Kościoła katolickiego, powołując się na godność i chrześcijańską miłość, wielokrotnie podkreślają, że szanują wszystkie już narodzone dzieci. W homilii ks. abpa Dzięgi, wygłoszonej na Jasnej Górze, odnaleźć można słowa skierowane właśnie do nich: Wy jesteście darem Bożej mitości dla świata, choć ten dar zostat przez dorostych wymuszony gwattem na naturze. Odetchnijcie gtębiej i swobodniej. Jesteście Bożymi dziećmi ${ }^{53}$. Ten dar miłości jest jednak okupiony ciężkim grzechem, o którym arcybiskup przypomina już w tym samym zdaniu. Wartym przytoczenia jest jednak także inny fragment jego wypowiedzi: To nie jest wasza wina, $\dot{z} e-a b y$ sie jedno $z$ was narodzito - to kilkadziesiąt innych dzieci musiato zamrzeć albo być zabitych. To nie jest wasza wina - za to odpowiedza dorośli przed Bogiem, ci, którzy to nakazali, którzy to zaproponowali $i^{54}$. Arcybiskup z jednej strony zapewnia o miłości i akceptacji Kościoła dla tych, którzy już się narodzili, a z drugiej nie pozwala zapomnieć o tym, że sama procedura jest zła i zasługuje na karę. Kontekst zapewnienia o Bożej miłości dla wszystkich poczętych dzieci jest więc bardzo specyficzny i rzeczywiście może prowadzić do problemów związanych z określeniem własnej tożsamości przez tych, którzy urodzili się dzięki in vitro. Wymagać będzie od nich przynajmniej przyjęcia do wiadomości, że narodzili się dzięki procedurze, w wyniku której część embrionów zostato zamrożonych lub skończyto swoja egzystencję $w$ zlewie ${ }^{55}$.

Miłość, o której zapewnia Kościół katolicki, a także dziennikarze i publicyści prezentujący podobne stanowisko, jest zatem podwójnie okupiona. Po pierwsze grzechem, którego dopuścili się rodzice i za który odpowiedzą. Po drugie tym, że za życie dorosłych już dzisiaj dzieci z in vitro zapłaciło ich rodzeństwo, które w fazie embrionalnej zostało zamrożone lub uśmiercone. W polskim dyskursie wciąż brakuje wypowiedzi osób z in vitro, które publicznie przyznają się do cierpienia z tych właśnie powodów. Niemniej jednak odnaleźć można polskie publikacje przywołujące te problemy w odniesieniu na przykład do osób innej narodowości. Na portalu fronda.pl ukazał się tekst zatytułowany Wstrzasające świadectwo dziecka $z$ in vitro: Chciatabym się nie narodzić, w którym opisano historię Brytyjki pochodzącej z heterologicznego ${ }^{56}$ in vitro. Opisano

51 Stenogram Sejmowy, 90. Posiedzenie Sejmu, 9 IV 2015, s. 180.

52 Tamże, s. 186.

53 A. Dzięga, Kazanie podczas mszy na XXIV Pielgrzymce Rodziny Radia Maryja na Jasną Górę 12 VII 2015, [online] http://www.radiomaryja.pl/kosciol/ks-abp-a-dziega-narod-polski-stac-na-to-by-powiedziec-nie, 13 VIII 2015.

54 Tamże.

55 J. Hlebowicz, Ideologiczne tsunami. Rozmowa z ks. D. Oko, „Gość Niedzielny” 2015, 26 IV.

$56 \mathrm{Z}$ zapłodnieniem in vitro heterologicznym mamy do czynienia wówczas, gdy przynajmniej jedna gameta nie pochodzi od współmałżonków (partnerów), analogicznie - in vitro homologiczne zakłada, że obie komórki rozrodcze pochodzą od współmałżonków, a więc rodziców, którzy będą wychowywać dziecko. 
w nim między innymi jej trudności związane z faktem, że nie jest biologicznym dzieckiem swoich społecznych rodziców, którzy uratowali ja z ciektego azotu ${ }^{57}$. Jej wypowiedź: są takie momenty, gdy pragnętabym nigdy się nie narodzić, i choć bardzo kocham moich rodziców, to jest bardzo trudne nie wiedzieć, kim sie jest i skąd się pochodzi ${ }^{58}$ - sugeruje problemy, z jakimi kiedyś mogą borykać się osoby w podobnej sytuacji, w której de facto nie można w żaden sposób dotrzeć do jakiejkolwiek informacji na temat swoich rodziców, rodzeństwa itp. Autor artykułu Tomasz Terlikowski pisze, że $d z i e w c z y-$ na zostata uratowana przez rodziców z wielkich beczek z ciektym azotem, $w$ których na nie-śmierć i nie-życie skazali ja jej genetyczni rodzice i lekarze ${ }^{59}$, i przywołuje obecny już w polskiej debacie tzw. syndrom ocaleńca. Podobny przypadek zaprezentowała w swoim tekście Małgorzata Terlikowska, opisując sytuację osoby, która urodziła się dzięki temu, że jej matka skorzystała z banku nasienia w Londynie. Autorka artykułu przytoczyła wypowiedzi zarówno córki, jak i matki. Pierwsza z nich mówi: Gdzieś na świecie mam z setkę, a może i więcej przyrodniego rodzeństwa. Wiesz, co czuję? Że to niesprawiedliwe. Ja o to nie prositam [...]. Nie prositam o to, żeby być rodzeństwem setki nieznajomych ludzi, nie prositam o to, żeby nie wiedzieć, kto jest moim biologicznym ojcem, nie móc się z nim skontaktować ${ }^{60}$. Gdy osiągnęła pełnoletniość, zaczęła poszukiwania swojego ojca - dawcy nasienia, ale te poszukiwania wywołały lęk u jej matki: Martwię się, że Ruth zostanie zraniona, że dawca, jeśli go znajdzie, odrzuci ja. Styszatam okropne historie. Dziewczyna znalazta dawce, a on nastraszyt ja policja. To koszmarnie niesprawiedliwe. To nie ich wina, że tak zostaty poczęte. To my to zrobiliśmy ${ }^{61}$.

Zespół ocaleńca przywołał także hierarcha Kościoła katolickiego abp Hoser w słowach: dzieci poczęte metoda in vitro, kiedy dorosna, będa stawiaty pytania co do swojego przeżycia tego niezwykle niebezpiecznego etapu, jakim byta ich selekcja do życia, zreszta kosztem innych ${ }^{62}$. Stanowisko Kościoła katolickiego sugeruje problemy tożsamościowe, jakie wywołać może świadomość, że przyszło się na świat kosztem innych osób. Niemniej jednak, poza mocnym akcentowaniem samego faktu „przeżycia”, trudno odnaleźć w wypowiedziach przedstawicieli Kościoła wskazania i przykłady rzeczywistych problemów z tożsamością.

Głos polskich dzieci poczętych in vitro wydaje się natomiast świadczyć o czymś zupełnie innym. Dowodzi tego choćby artykuł Cośw nich pękto. Dzieci z in vitro wychodza

57 T. Terlikowski, Wstrzasające świadectwo dziecka $z$ in vitro: Chciatabym się nie narodzić, 1 VII 2014, [online] http://www.fronda.pl/a/wstrzasajace-swiadectwo-dziecka-z-in-vitro-chcialabym-sie-nie-narodzic,39049.html, 13 VIII 2015.

58 Tamże.

59 Tamże.

60 M. Terlikowska, „Ludzie tworzyli dzieci jak lalki”, czyli ciemna strona in vitro, 22 III 2015, [online] http://www.fronda.pl/a/terlikowska-ludzie-tworzyli-dzieci-jak-lalki-czyli-ciemna-strona-in-vitro, 48956.html?part=2, 14 VIII 2015.

61 Tamże.

62 Wypowiedź abpa H. Hosera przywołana w artykule „Gazety Wyborczej”, 12 IV 2013, [online] http:// wyborcza.pl/1,76842,13729657,Episkopat_odpowiada_urodzonej_z_in_vitro_ktora_chce.html, 14 X 2015. 
$z$ szafy. Sam tytuł sugeruje, że do tej pory pozostawały w cieniu, nie brały udziału w dyskusji, a jedynie słuchały tego, co mówi się na ich temat. Wypowiada się w nim między innymi urodzona w 1989 roku Karolina: To nieistotne, czy jestem z probówki czy nie. Jestem cztowiekiem. Ważne tylko, czy dobrym, a nie, czy poczetym w tóżku, na stole, podtodze czy na szkietku laboratoryjnym. Moi rodzice sa, mam nadzieje, ze mnie dumni i najważniejsze, $\dot{z} e e^{e s t e m}{ }^{63}$. W podobnym tonie wypowiedziała się Magda: Przeżytam ogromny szok, kiedy w okresie dojrzewania dotarty do mnie wypowiedzi, że jestem owocem ogromnego grzechu, że nie powinno mnie być na tym świecie. Wszystkie swoje porażki traktowatam jako kare od Boga, czutam się gorsza, czutam, że Bóg nie chce żebym żyta! ${ }^{64}$ Dodała także, że to nie metoda zaptodnienia sprawia, że dzieci zin vitro moga zmagać się z problemami emocjonalnymi. To kościót Katolicki oraz wszyscy jego poplecznicy, którzy nas stygmatyzują i odsuwaja od spoteczeństwa [...]. To nie my jesteśmy źli. Źli sq wszyscy, którzy zabraniaja nam żyć, a zwtaszcza politycy o skrajnych i niebezpiecznych poglądach, bezrefleksyjni przedstawiciele Kościota Katolickiego oraz wszyscy, którzy robią z nas potwory i najchętniej by się wszystkich pozbyli ${ }^{65}$.

W związku z powyższymi wypowiedziami rodzi się pytanie o to, czy problemy tożsamościowe osób urodzonych dzięki in vitro wynikają rzeczywiście z faktu poczęcia na szkle, w laboratorium i kosztem życia swojego rodzeństwa, czy przywołują je do debaty przeciwnicy tej metody zapłodnienia, tak jak przywołano wcześniej zarodki i kwestię ich zamrażania czy przechowywania. Paradoksalnie, nieustanne zapewnienia Kościoła katolickiego i wszystkich przywołujących jego argumenty o miłości i szacunku dla wszystkich poczętych in vitro wpadają niejako w próżnię. Nikt z reprezentantów drugiej strony sporu ich nie uwzględnia. Pozostają niesłyszalne dla propagatorów tej metody, rodziców dzieci z in vitro, a także dla nich samych. Dużo bardziej słyszalnym jest głos o tym, że narodziły się w wyniku grzechu.

Argumenty polskiej debaty o in vitro od wielu lat koncentrują się wokół odpowiedzi na pytanie, kiedy zaczyna się człowiek i czy zarodki to już ludzie, czy też dopiero potencjalni członkowie społeczeństwa. W ostatnich latach, a szczególnie w trakcie debaty nad przyjętą w lipcu 2015 roku ustawą o leczeniu niepłodności, przeciwnicy tego zabiegu przywołali dodatkowo problemy tożsamościowe osób poczętych dzięki in vitro. W ten sposób polski dyskurs, choć wciąż mający za swoją podstawę spór o to, jaki status ma zarodek i jakie zabiegi na nim są dopuszczalne, wzbogacił się o dodatkowy wątek. Podobnie jak kilka lat temu przywołano do debaty „zamrożone zarodki”, tak od 2012 roku w debacie uczestniczą "dzieci z in vitro”. Pojawiają się w niej w podwójnej roli - przedmiotu i podmiotu (uczestnika) dyskursu. Istotne jest jednak to, że one same o swoich problemach mówią zupełnie inaczej aniżeli przeciwnicy in vitro ${ }^{66}$.

63 Wypowiedź Karoliny w: M. Bratkowska, M. Wilgocki, Cośw nich pękto. Dziecizin vitro wychodzązsza$f y$, „Gazeta Wyborcza” 2015, 18 VII, [online] http://wyborcza.pl/magazyn/1,146875,18384282,cos-w-nich-peklo-dzieci-z-in-vitro-wychodza-z-szafy.html, 13 VII 2015.

64 Wypowiedź Magdy w: tamże.

65 M. Kołodziej, Apel do mediów, 10 VII 2015, [online] http://www.nasz-bocian.pl/node/52333, 14 VIII 2015.

${ }^{6}$ Wynikać to jednak może z tego, że w Polsce wciąż rzadko korzysta się banków nasienia i niewiele w samej debacie mówi się o adopcji zarodków. 
Nie przyznają się do „syndromu ocaleńca” i nie pytają o swoje potencjalne rodzeństwo. Problemem jest dla nich ciągłe przypominanie im o tym, że nie poczęły się naturalnie, lecz na laboratoryjnym szkle. Dla nich liczy się to, że żyją i że w ogóle mogły się urodzić, a jako stygmatyzujące traktują wypowiedzi przedstawicieli Kościoła katolickiego i posłów z prawej strony sceny politycznej, które przypominają im, że przyszły na świat w wyniku selekcji eugenicznej. Próbując opisać proces kształtowania ich tożsamości, pamiętać należy także o tym, że niejednokrotnie deklarują oni wiarę w Boga i przywiązanie do tradycji katolickiej, odrzucając jednocześnie nauczanie Kościoła w kwestii in vitro. Niemniej jednak w polskiej debacie wciąż niewiele jest osób otwarcie mówiących o tym, że przyszły na świat w wyniku in vitro, sporo osób po prostu o tym nie wie, stąd też nie są oni reprezentatywną próbą. W polskich publikacjach pojawią się natomiast przykłady osób z Wielkiej Brytanii czy USA, które z problemami dotyczącymi swojej tożsamości rzeczywiście się zmagają ${ }^{67}$.

\section{WNIOSKI}

Luhmannowska wizja systemu polityki zakłada, że chcąc zachować swoją tożsamość i odrębność od otoczenia, redukuje on swoją złożoność. W analizowanych dyskusjach wokół prac nad ustawą o leczeniu niepłodności system mógł redukować złożoność według dwóch możliwych scenariuszy: przyjmując rozwiązania prawne wzorowane na innych państwach, jednocześnie próbując uniknąć tzw. „sporów światopoglądowych” (i), albo ujmując problem zapłodnienia in vitro za pomocą binarnego kodu etycznego, który definiuje, co jest dobre, a co złe, i automatycznie odrzucając część możliwych rozwiązań przez etyczną klasyfikację (ii).

Polski system polityki działał według drugiego scenariusza, starając się podczas prac nad ustawą o leczeniu niepłodności określić, które z zagadnień związanych z procedurą zapłodnienia in vitro są dopuszczalne, a które nie ${ }^{68}$. Łatwo jednak zauważyć, że struktura argumentów, jakie pojawiły się w polskim dyskursie, nie tylko nie zmierzała do konstruktywnego rozwiązania tego zagadnienia. Używając terminologii Luhmanna, system polityki nie tylko nie redukował złożoności, lecz - w reakcji na ciągle powstające wątpliwości i dyskusje - nieustannie ją pogłębiał. Debata publiczna rozszerzała się o coraz to nowe wątki, tworząc dodatkowe linie podziałów i tym samym pogłębiając, istniejący już i tak od dwóch dekad, „rytualny chaos”. Pogłębianie złożoności w obrębie systemu polityki wynikało z dwóch zasadniczych powodów.

Po pierwsze przywołano do debaty osoby poczęte dzięki in vitro i wskazano na nowe problemy, z jakimi mogą mieć do czynienia w przyszłości. W debacie zaistniała

\footnotetext{
${ }_{67}$ Najczęściej autorzy artykułów powołują się na amerykańską Commission on Parenthood's Future, skupiającą badaczy z różnych uniwersytetów z USA, która opublikowała raport pod tytułem My Daddy's Name is Donor, przetłumaczony później w jednej z publikacji na fronda.pl.

68 Mając na uwadze przede wszystkim możliwość mrożenia „zarodków nadliczbowych” i określając maksymalny czas ich przechowywania, dopuszczalność in vitro dla par, które nie są małżeństwem, zakaz eksperymentów na embrionach itd.
} 
dodatkowa grupa artykułująca swoje poglądy, która w polskim dyskursie funkcjonuje, jak dotąd, tylko po jednej stronie sporu i wspiera argumenty zwolenników tej metody. Niemniej jednak przeciwnicy in vitro przywołują w swoich wypowiedziach świadectwa dzieci innych narodowości, które mogą być dowodem problemów wywołanych tą metodą zapłodnienia.

Po drugie pogłębianie złożoności systemu polityki wynika z tego, że zapowiedź ustawowej regulacji procedury zapłodnienia in vitro wywołała w tym systemie konieczność rozpatrzenia wielu alternatywnych rozwiązań. W toku prac legislacyjnych pojawiło się całkiem sporo alternatywnych rozwiązań, z których przyjęte mogło być tylko jedno. System, chcąc zachować swoją tożsamość, zmuszony jest do redukcji złożoności właśnie poprzez eliminowanie tych alternatyw, które są dla niego nie do przyjęcia.

Ponadto w toku prac nad ustawą o leczeniu niepłodności pojawiały się ograniczenia, stwarzane przede wszystkim przez system religii, do których system polityki z konieczności musiał się odnieść. Współgra to z jednym z założeń Luhmanna o możliwościach działania "rozsadzających” system polityki siłą religii. Świadczyć może o tym chociażby przywołana do debaty kwestia ekskomuniki tych polityków, którzy wyrazili poparcie dla przyjętej w lipcu 2015 roku ustawy o leczeniu niepłodności. Można także zaryzykować tezę, że nie do końca sprawdza się założenie Luhmanna o dyferencjacji funkcjonalnej i wyodrębnianiu się podsystemu religii. Ten ostatni, biorąc pod uwagę polską debatę o in vitro, nie do końca oddzielił się od systemu polityki.

Sytuacja ta jest wynikiem szczególnego modelu relacji państwo-Kościół, który funkcjonuje w Polsce. Kwestia in vitro jest dla systemu zagadnieniem wywołującym debatę na temat podstawy aksjologicznej nowoczesnego społeczeństwa, którym od 1989 roku staje się społeczeństwo polskie. Ten specyficzny model relacji wynika z tego, że w okresie PRL to Kościół katolicki stał się oazą dla opozycji i tym samym przestrzenią, w której kształtowały się zalążki społeczeństwa obywatelskiego. Była to sytuacja szczególna i na tle pozostałych państw wyjątkowa, bo Kościół przyciągał dysydentów politycznych, bez względu na ich osobisty stosunek do religii. Funkcję społeczeństwa obywatelskiego Kościół katolicki pełnił więc zastępczo i po 1989 roku musiało się to zmienić. Był to w okresie transformacji ustrojowej dodatkowy czynnik, określający pozycję i znaczenie religii w polskiej przestrzeni publicznej. Współcześnie, w przypadku dyskursu o in vitro, to zwolennicy tej metody określają siebie jako ruch społeczny i tym samym przejaw kształtującego się od lat 90. XX wieku społeczeństwa obywatelskiego oraz forma uzewnętrzniania tożsamości zbiorowej ${ }^{69}$. Stanowisko Kościoła katolickiego i osób przeciwnych in vitro traktowane jest jako głos tych, którzy sprzeciwiają się postępowi, modernizacji czy powrotowi do Europy, co biorąc pod uwagę rolę Kościoła przed 1989 roku, jest szczególnie znaczące. Trudno wszak odmówić środowiskom przeciwnym in vitro działalności na rzecz właśnie pluralistycznego społeczeństwa obywatelskiego - tego typu zabiegi są jednak w Polsce stosowane, czego dowiodły chociażby ostatnie debaty na temat próby wprowadzenia całkowitego zakazu aborcji. Zwolennicy

69 Por. E. Korolczuk, Nieptodność, tożsamość, obywatelstwo. Analiza spotecznej mobilizacji wokót dostępu do in vitro w Polsce, [w:] Etnografie biomedycyny, red. M. Radkowska-Walkowicz, H. Wierciński, Warszawa 2014. 
in vitro swoją aktywność identyfikują przede wszystkim z procesami modernizacji i europeizacji Polski, przywracającymi jej miejsce w Europie Zachodniej, podczas gdy swoich oponentów określają jako tych, którzy nie tylko nie są otwarci na zmiany współczesnego świata, ale także chcą ingerować w prywatną sferę życia obywateli, określając im sztywno zakres wolności ${ }^{70}$. Ich aktywność odbiega znacznie od nauki Kościoła, choć oni sami tego nie podkreślają, wskazując raczej, że argumentów religijnych przeciwko in vitro po prostu nie rozumieją. Jest to całkiem jaskrawy przejaw zmieniających się nieustannie od ponad 25 lat relacji państwo-Kościół, ale także przejaw zmieniającego się modelu budowania własnej tożsamości.

Znamiennym jest także i to, że w przypadku debaty nad wspomnianą ustawą obie strony sporu nie dążyły do stworzenia rozwiązania kompromisowego, tak jak miało to miejsce w przypadku prac nad ustawą aborcyjną z lat 90. XX wieku. Polską debatę publiczną charakteryzuje już nie tylko opisany przez Marka Czyżewskiego „rytualny chaos”, ale nieustanne wręcz usztywnianie stanowisk każdej ze stron sporu. Kompromis (nawet ten aborcyjny) jest zdaniem przedstawicieli Kościoła katolickiego zawsze „zgniły etycznie", ale mimo wszystko jest efektem dążeń do porozumienia. Tego ostatniego w przypadku prac nad ustawą o leczeniu niepłodności właściwie nie można zaobserwować. Być może poza jednym stanowiskiem Kościoła katolickiego wyrażonym przez Komisję Episkopatu Polski w marcu 2015 roku, w którym podkreślono, że każdy embrion ludzki musi być traktowany z godnościa jako podmiot, a nie przedmiot oraz że niedopuszczalne jest również poddawanie go procedurze selekcji, mrożeniu, modyfikacji, [...] nie do zaakceptowania jest tworzenie zarodków do ewentualnego wykorzystania w przysztości ${ }^{71}$. W cytowanym dokumencie wskazano, że Kościół dąży do porozumienia w sprawie in vitro i że biskupi są świadomi konieczności ustawowego uregulowania tej kwestii. Politycy popierający przyjęty ostatecznie projekt ustawy nie uznawali jednak tych założeń za dążenie do kompromisu. To stanowisko Kościoła katolickiego uwzględnił właściwie tylko jeden projekt ustawy o in vitro, autorstwa posła Jarosława Gowina. Projektu tego nie poparła jednak żadna licząca się siła polityczna, co wynika głównie z pogłębiającej się, zwłaszcza w okresie przedwyborczym, polaryzacji sceny politycznej. Stanowisko wobec in vitro wyrażało się bowiem w polskim dyskursie politycznym w retoryce dwóch głównych partii: PO i PiS, które w zależności od prezentowanego światopoglądu były za lub przeciw tej metodzie zapłodnienia. W warunkach coraz bardziej usztywnianych stanowisk dwóch stron kompromis staje się właściwie niemożliwy. Paradoksalnie łatwiej było go osiągnąć w przypadku ustawy regulującej dostęp do zabiegu aborcji w 1993 roku, kiedy polska scena polityczna była bardziej zróżnicowana i w Sejmie zasiadało wiele mniejszych partii.

70 Dowodzą tego wszystkie spory natury aksjologicznej, jakie w ostatnim czasie dominowały w polskim dyskursie. Najbardziej jaskrawym przejawem podziału na grupy „światłych obywateli” i tych przywiązanych do tradycyjnych wartości Kościoła katolickiego był „czarny protest” Polek opowiadających się przeciwko próbom wprowadzenia całkowitego zakazu aborcji w Polsce.

71 Gtos Prezydium Konferencji Episkopatu Polski w kontekście przygotowywanej ustawy o leczeniu nieptodności, 4 III 2015, [online] http://episkopat.pl/struktura_kep/prezydium_kep/6504.1,Glos_Prezydium_Konferencji_Episkopatu_Polski_w_kontekscie_przygotowywanej_ustawy_o_leczeniu_nieplodnosci.html, 17 X 2015. 
Poza wspomnianym stanowiskiem KEP, system religii, reagując na rosnącą złożoność w swoich granicach, starał się przede wszystkim poświęcić analizowanemu problemowi jak najwięcej miejsca w różnego rodzaju aktach komunikacji. Stąd też wynika coraz większa liczba publikacji poświęconych in vitro w miesiącach ${ }^{72}$, w których odbywały się sejmowe debaty nad projektem przyjętej w lipcu 2015 roku ustawy o leczeniu niepłodności. Zakładając, że zmiana stanowiska jest w gruncie rzeczy niemożliwa, system przyjął za konieczne jak najlepsze informowanie o przyczynach takiego, a nie innego poglądu w sprawie in vitro.

Czas procesów demokratyzacji i europeizacji sprawił, że polskie społeczeństwo stawało się coraz bardziej spluralizowane i poszukujące coraz to nowych i coraz bardziej zróżnicowanych stylów życia, czego dowodzą działające w analizowanym obszarze organizacje i grupy społeczne reprezentujące zarówno stanowiska popierające in vitro, jak i im przeciwne. Wciąż jednak nie określono, jaką rolę w tym społeczeństwie odgrywają wartości reprezentowane przez Kościół katolicki, które w polskiej debacie publicznej są albo całkowicie odrzucane, albo wskazywane jako podstawa aksjologiczna dla całego narodu. W wypracowywaniu ostatecznego modelu tych relacji aktywnie uczestniczą przedstawiciele Kościoła, zabierając głos najczęściej w trakcie politycznych sporów o charakterze światopoglądowym, wskazując, że katolik bez względu na to, czy w przestrzeni publicznej, czy prywatnej, ma jasno określoną tożsamość i nie można wymagać od niego przyjmowania dwóch modeli aksjologicznych - odrębnych dla obu tych obszarów. Zupełnie inaczej w przypadku analizowanego sporu określają siebie zwolennicy in vitro lub osoby, które korzystały z tej metody albo urodziły się dzięki niej. Dla nich poparcie dla in vitro nie oznacza rezygnacji z przynależności do Kościoła, choć pojawiały się także i takie pojedyncze głosy ${ }^{73}$, a tym bardziej porzucenia swojej wiary czy tradycji. Dlatego też debata na temat problemów światopoglądowych w Polsce jest niezwykle trudna do scharakteryzowania, nie tylko dlatego, że cechuje ją wspomniany „rytualny chaos", ale także dlatego, że jej uczestnicy przywołują w uzasadnianiu swoich stanowisk różne wartości, niekiedy trudne do pogodzenia. Potwierdza to chociażby powoływanie się na tożsamość katolicką zarówno tych posłów, którzy głosowali za przyjęciem ustawy o leczeniu niepłodności, jak i jej zagorzałych przeciwników. Po uwzględnieniu wątków przywołanych w niniejszym tekście właściwa wydaje się konstatacja o „specyficznym” znaczeniu religii w polskiej debacie publicznej, którą uwzględniać powinien przyjęty przez Polskę model relacji państwo-Kościół. Kościół instytucjonalny nie jest bowiem

72 Dla przykładu, w lipcu 2015 roku niemal w każdym numerze „Gościa Niedzielnego” opublikowano artykuł na temat in vitro, a w maju tego samego roku nie było żadnego dłuższego tekstu poświęconego tej tematyce.

73 Najbardziej znana była sprawa Agnieszki, pierwszej Polki poczętej dzięki in vitro, która ogłosiła na jednym z portali społecznościowych, że zamierza dokonać aktu apostazji. Jej decyzja stała się przyczyną wielu publikacji i dyskusji dotyczących ewentualnego występowania z Kościoła katolickiego osób poczętych tą metodą. 
ani „zwyczajnym” aktorem politycznym (realizującym konkretne cele), jak określają go przedstawiciele partii lewicowych, ani fundamentem współczesnego narodu i państwa, jak chcieliby politycy polskiej prawicy.

Debata o kwestiach światopoglądowych, która tak mocno zdominowała polską przestrzeń publiczną w latach 90. XX wieku, właściwie trwa do dzisiaj. Widoczne są w niej spory pomiędzy zakresem indywidualnej wolności i prawem wyboru oraz prawem społeczności do zachowania swojej tożsamości, w której sporą rolę odgrywa religia. Procesy modernizacji „wymuszają" regulację coraz to nowych zagadnień, które w polskich warunkach nieustannie odnawiają też spór o naturę relacji państwo-Kościól. W wielogłosowej sferze publicznej artykułowane i uzasadniane są zarówno poglądy wierzących, jak i niewierzących, jakkolwiek ci ostatni nie mogą funkcjonować w zupełnym oderwaniu od głosu tych, dla których religia odgrywa znaczącą rolę w przyjmowanym systemie znaczeń i wartości. Dowodzić to może słuszności tezy Jürgena Habermasa o tym, że nawet w nowoczesnym modelu państwa demokratycznego, oddzielającego sferę polityczną od religijnej, religia może mieć swoją rolę do odegrania $^{74}$. Wymaga jednak, podążając za habermasowskimi założeniami, realizowania tzw. „działania komunikacyjnego”, które w polskich warunkach wydaje się wciąż trudne do osiągnięcia. Analiza polskiej debaty publicznej pokazuje nie tylko dominujący w niej, uniemożliwiający kompromis, spór o uniwersa symboliczne, ale także jej brutalizację i instrumentalizację, które w konsekwencji doprowadzają do polaryzacji sceny politycznej i uwypuklenia stanowisk dwóch dominujących partii oraz marginalizacji pozostatych stanowisk. Rola religii pozostaje w tak określonym systemie polityki wciąż niezdefiniowana i tym samym jej argumenty ujawniają się w sporach politycznych w sposób nieustrukturyzowany, zaburzając niejednokrotnie proces polityczny i uniemożliwiając jego sprawne funkcjonowanie. W przeciwieństwie do systemu religii system polityki napotyka trudności z ujęciem pewnych problemów za pomocą binarnego kodu etycznego, głównie ze względu na konieczność zapewniania obywatelom nie tylko wolności od ingerencji w ich sferę prywatną, ale także wolności do wyrażania swoich poglądów.

\section{BIBLIOGRAFIA}

Borowik I., Religia jako element tożsamości $w$ warunkach transformacji $w$ Europie Środkowo-Wschodniej, [w:] Państwo - spoteczeństwo - religia we wspótczesnej Europie, red. M. Mróz, T. Dębowski, Toruń 2009.

Bratkowska M., Wilgocki M., Cośw nich pękto. Dzieci z in vitro wychodza z szafy, „Gazeta Wyborcza” 2015, 18 VII, [online] http://wyborcza.pl/magazyn/1,146875,18384282,cos-w-nich-peklo-dzieci-z-in-vitro-wychodza-z-szafy.html.

74 J. Habermas, Religion in the Public Sphere, „European Journal of Philosophy” 2006, Vol. 14, nr 1, s. 1-25; tenże, Wierzyć i wiedzié, przeł. M. Łukasiewicz, „Znak” 2002, nr 568 (9), s. 8-21; P. Burgoński, Kościót wobec pluralizmu sfery publicznej, „Chrześcijaństwo - Świat - Polityka” 2014, nr 1/2 (15/16), s. 54-64. 
Burgoński P., Kościót wobec pluralizmu sfery publicznej, „Chrześcijaństwo - Świat - Polityka” 2014, nr 1/2 (15/16).

Butkiewicz-Brożek J., Obtęd Edwardsa, „Gość Niedzielny” 2015, 2 VII, [online] http://gosc.pl/ doc/2569238. Obled-Edwardsa.

Chiouliaraki L., Discourse Analysis, [w:] The SAGE Handbook of Cultural Analysis, eds. T. Bennett, J. Frow, Los Angeles 2008.

Chore dzieci z probówki, 24 III 2009, [online] http://www.fronda.pl/a/chore-dzieci-z-probowki, 1288.html.

Czyżewski M., Dunin K., Piotrowski A. (red.), Cudze problemy. O ważności tego, co nieważne, Warszawa 1991.

Czyżewski M., Kowalski S., Piotrowski A., Rytualny chaos. Studium dyskursu publicznego. Kraków 1997.

Dzięga A., Kazanie podczas mszy na XXIV Pielgrzymce Rodziny Radia Maryja na Jasna Górę 12 VII 2015, [online] http://www.radiomaryja.pl/kosciol/ks-abp-a-dziega-narodpolski-stac-na-to-by-powiedziec-nie.

Dziuban A., System religijny w dobie globalizacji. Inkluzja i fundamentalizm z perspektywy teorii systemowej Niklasa Luhmanna, „Poznańskie Studia Teologiczne” 2008, Vol. 22.

Gtos Prezydium Konferencji Episkopatu Polski w kontekście przygotowywanej ustawy o leczeniu nieptodności, 4 III 2015, [online] http://episkopat.pl/struktura_kep/prezydium_kep/6504.1,Glos_Prezydium_Konferencji_Episkopatu_Polski_w_kontekscie_przygotowywanej_ustawy_o_leczeniu_nieplodnosci.html.

Grekokatolicy $i$ prawostawni o in vitro, [online] http://www.grekokatolicy.pl/aktualnosci/ grekokatolicy-i-prawoslawni-wobec-in-vitro.html.

Habermas J., Religion in the Public Sphere, „European Journal of Philosophy” 2006, Vol. 14, nr 1. Habermas J., Wierzyć i wiedzieć, przeł. M. Łukasiewicz, „Znak” 2002, nr 568 (9).

Hamida F.B., Moralność muzutmańska wobec medycyny i biotechnologii, [w:] Medycyna a prawa cztowieka. Normy i zasady prawa międzynarodowego, etyki oraz moralności katolickiej, protestanckiej, żydowskiej muzutmańskiej i buddyjskiej, przeł. I. Kaczyńska, Warszawa 1996.

Hlebowicz J., Ideologiczne tsunami. Rozmowa z ks. D. Oko, „Gość Niedzielny” 2015, 26 IV.

In vitro znów w Sejmie. „To jest spór światopoglądowy”, [online] http://www.polskieradio. $\mathrm{pl} / 7 / 473 /$ Artykul/1416858, In-vitro-znow-w-Sejmie-To-jest-spor-swiatopogladowy.

Instrukcja o szacunku dla rodzącego się zycia ludzkiego i o godności jego przekazywania. Odpowiedzi na niektóre aktualne zagadnienia, 12 II 1987, [online] http://www.vatican.va/roman_curia/congregations/cfaith/documents/rc_con_cfaith_doc_19870222_respect-for-human-life_pl.html.

Kołodziej M., Apel do mediów, 10 VII 2015, [online] http://www.nasz-bocian.pl/node/52333.

Korolczuk E., Nieptodność, tożsamość, obywatelstwo. Analiza spotecznej mobilizacji wokót dostępu do in vitro $w$ Polsce, [w:] Etnografie biomedycyny, red. M. Radkowska-Walkowicz, H. Wierciński, Warszawa 2014.

Kozub-Karkut M., Głuszek-Szafraniec D., Miejsce krzyża w przestrzeni publicznej - analiza wybranych debat, „Studia Religiologica” 2016, z. 1, [online] http://www.ejournals.eu/Studia-Religiologica/Tom-49-2016/Numer-49-1-2016/art/7281, https://doi.org/10.4467/2084 4077SR.16.004.4904. 
Ksiąd ttumaczy się ze stów o bruzdach na twarzach dzieci z in vitro, [online] http://www.tvn24. $\mathrm{pl}$ /wiadomosci-z-kraju,3/ksiadz-tlumaczy-sie-ze-slow-o-bruzdach-na-twarzach-dzieci-z-in-vitro,308217.html.

Longchamps de Bérier F., In vitro niczego nie zatatwia, rozmowa z T. Krzyżakiem, „Uważam Rze" 2014, 28 II.

Luhmann N., Systemy spoteczne. Zarys ogólnej teorii, przeł. M. Kaczmarczyk, Kraków 2007, Wspótczesne Teorie Socjologiczne, 1.

Łoziński B., Argument przeciwko in vitro, „Gość Niedzielny” 2015, 22 II.

Mój ojciec nazywa się Dawca, czyli co trapi dzieci z próbówki?, 14 VI 2010, [online] http://www. fronda.pl/a/moj-ojciec-nazywa-sie-dawca-czyli-co-trapi-dzieci-z-probowki,6939.html.

Pawliszak P., Rancew-Sikora D., Wprowadzenie do socjologicznej analizy dyskursu, „Studia Socjologiczne" 2012, Vol. 1, nr 204.

Pieronek T., Pierwowzorem in vitro jest Frankeinstein, w rozmowie z W. Harpulą, 15 I 2009, [online] http://wiadomosci.onet.pl/pierwowzorem-in-vitro-jest-frankenstein/x4d6q.

Radkowska-Walkowicz M., Doświadczenie in vitro. Nieptodnośc i nowe technologie reprodukcyjne w perspektywie antropologicznej, Warszawa 2013.

Radkowska-Walkowicz M., Frozen children and despairing embryos in the new post-communist state. Debate on IVF in the context of Poland's transition, „European Journal of Women's Studies" 2014, Vol. 21, nr 4, [online] https://doi.org/10.1177/1350506814542881.

Reisigl M., Analiza retoryki politycznej, [w:] Jakościowa analiza dyskursu w naukach spotecznych, red. nauk. R. Wodak, M. Krzyżanowski, przeł. D. Przepiórkowska, Warszawa 2011, Biblioteka Dyskursu Publicznego.

Sadurska M., wypowiedź dla Programu Pierwszego Polskiego Radia.

Salij J., O zaptodnieniu in vitro porozmawiajmy spokojnie, 12 V 2008, [online] http://www.stronaoinvitro.pl/salij-in-vitro.

Sejm uchwalit ustawę o in vitro. Premier Ewa Kopacz: „Dotrzymatam stowa”, [online] https:// www.premier.gov.pl/wydarzenia/aktualnosci/sejm-uchwalil-ustawe-o-in-vitro-premier-ewa-kopacz-dotrzymalam-slowa.html.

Skąpska G., Niklas Luhmann i teoria systemów spotecznych. Wstęp do wydania polskiego, [w:] Luhmann N., Systemy spoteczne. Zarys ogólnej teorii, przeł. M. Kaczmarczyk, Kraków 2012, Wspótczesne Teorie Socjologiczne, 1.

Skąpska G., Wstęp, [w:] N. Luhmann, Teoria polityczna państwa bezpieczeństwa socjalnego, przeł. G. Skąpska, Warszawa 1994.

Skrzypulec B., Dyskurs na temat legalnych substancji psychoaktywnych w perspektywie teorii systemowej Niklasa Luhmanna, „Studia Socjologiczne” 2004, Vol. 1, nr 204.

Staszewski W., Czy Bóg lubi seks? Wywiad z prof. Andrzejem Jaczewskim, „Newsweek” 2015, 27 VII. Stenogram Sejmowy, 90. Posiedzenie Sejmu, 9 IV 2015.

Stępień M., Dlaczego nienawidzę dzieci z probówki, 2 VII 2012, [online] http://www.fronda.pl/ blogi/gloria-tibi-domine/dlaczego-nienawidze-dzieci-z-probowki,28590.html.

Synod o dopuszczalności in vitro, 19 IV 2009, [online] http://old.luteranie.pl/pl/?D=2676.

Szacki J., Historia myśli socjologicznej, Warszawa 2006.

Terlikowska M., „Ludzie tworzyli dzieci jak lalki, czyli ciemna strona in vitro, 22 III 2015, [online] 
http://www.fronda.pl/a/terlikowska-ludzie-tworzyli-dzieci-jak-lalki-czyli-ciemna-stronain vitro, 48956.html ?part=2.

Terlikowski T., Wstrzasające świadectwo dziecka $z$ in vitro: Chciatabym się nie narodzić, 1 VII 2014, [online] http://www.fronda.pl/a/wstrzasajace-swiadectwo-dziecka-z-in-vitro-chcia labym-sie-nie-narodzic,39049.html.

Van Dijk T.A., Badania nad dyskursem, [w:] Dyskurs jako struktura i proces, red. T.A. van Dijk, przeł. G. Grochowski, Warszawa 2001.

Wodak R., Wstęp: Badania nad dyskursem - ważne pojęcia i terminy, [w:] Jakościowa analiza dyskursu w naukach spotecznych, red. nauk. R. Wodak, M. Krzyżanowski, przeł. D. Przepiórkowska, Warszawa 2011, Biblioteka Dyskursu Publicznego.

Zawała M., Agnieszka Ziótkowska to najstarsze w Polsce dziecko poczęte metodą in vitro, [online] http://www.dziennikzachodni.pl/artykul/793914,agnieszka-ziolkowska-to-najstarsze-w-polsce-dziecko-poczete-metoda-in-vitro,id,t.html.

Zelnik: rodzq się z tego in vitro dzieci koszmarnie chore, potamane. Ekspert: gruba przesada, [online] http://www.tvn24.pl/wiadomosci-z-kraju,3/jerzy-zelnik-i-maciej-malenczuk-w-tak-jest-spor-o-in-vitro, 546318.html.

Ziółkowska A., My, dzieci Frankensteina. Żjemy, pracujemy, kochamy oraz GEOSUJEMY. Nie zapomnimy Wam tej dyskusji [list o in vitro], „Gazeta Wyborcza” 2015, 9 VII, [online] http:// wyborcza.pl/1,95892,18331376,my-dzieci-frankensteina-zyjemy-pracujemy-kochamy-oraz-glosujemy.html. Ziółkowska A., Niepokalanie poczęta. Agnieszka, najstarsze w Polsce dziecko z in vitro, „Gazeta Wyborcza” 2012, 30 VI, [online] http://wyborcza.pl/energiakobiet/1,118219,12200284,Niepokalanie_poczeta_Agnieszka_najstarsze_w_Polsce.html.

Magdalena KOZUB-KARKUT - doktor nauk humanistycznych, asystent w Zakładzie Metodologii i Teorii Polityki w Wyższej Szkole Administracji w Bielsku-Białej. Absolwentka Instytutu Nauk Politycznych i Stosunków Międzynarodowych UJ. Członkini Polskiego Towarzystwa Studiów Międzynarodowych oraz European International Science Association. Uczestniczka seminariów, warsztatów i konferencji międzynarodowych, m.in.: 8th Pan-European Conference on International Relations - One International Relations or Many? Multiple Worlds, Multiple Crises; Garnet PhD School - Global Governance, Regionalism and the Role of the EU, EUSOC - European Graduate School for the Social Sciences. Zainteresowania badawcze: teorie stosunków międzynarodowych, procesy globalizacji w międzynarodowych stosunkach politycznych. 